\author{
Nota Científica \\ (Short Communication)
}

\title{
A DUNG BEETLE IN MEXICO CITY: THE CASE OF CERATOTRUPES FRONTICORNIS (ERICHSON) (COLEOPTERA: GEOTRUPIDAE)
}

Recibido: 20/11/2015; aceptado: 13/04/2016

\begin{abstract}
Ramírez-Restrepo, L. \& Halffter, G. 2016. A dung beetle in Mexico City: the case of Ceratotrupes fronticornis (Erichson) (Coleoptera: Geotrupidae). [Un escarabajo estercolero en la Ciudad de México: el caso de Ceratotrupes fronticornis (Erichson) (Coleoptera: Geotrupidae)]. Acta Zoológica Mexicana (n.s.), 32(2): 213-214.
\end{abstract}

RESUMEN. Ceratotrupes fronticornis (Erichson) es un escarabajo estercolero de tamaño mediano, perteneciente a la subfamilia Geotrupinae (Coleoptera: Scarabaeoidea: Geotrupidae). Es endémico de México, distribuyéndose en la zona montañosa alta del Sistema Volcánico Transversal. En esta nota señalamos la presencia de esta especie en dos áreas urbanas (Cuajimalpa y Magdalena Contreras) de la Ciudad de México. Adicionalmente, recalcamos la plasticidad ecológica de $C$. fronticornis en ambientes urbanos, al utilizar una fuente de alimento alternativa y abundante como es el excremento de perro doméstico.

Urbanization is one of the main threats to biodiversity (Czech et al. 2000). Nowadays more than half of human population lives in cities, and in Latin American countries, more than $70 \%$ of human population lives in urban areas (UN 2014). Thus, urbanization represents a major challenge for the biodiversity that lives in or near urban areas (Vitousek et al. 1997). The study of biodiversity and its response to urbanization has gained importance (McKinney 2008, McIntyre 2000), but there is still a lack of information for many species and biological groups (McIntyre 2000).

Among biological indicator groups, dung beetles have been widely studied (Favila \& Halffter 1997, Spector 2006) mainly in productive and wild environments such as ranching, farming and in nature reserves (Davis et al. 2001, Halffter \& Arellano 2002). However, few publications address the study of dung beetles in urban environments (Ramírez-Restrepo \& Halffter 2016). Urbanization has led to the local extinction of several dung beetles. In Rome five dung beetle species that used to be common in the urban area are now extinct (Fattorini 2011). Therefore, it is very important to know what species inhabit urban environments in order to detect losses and/or gains of species due to urbanization over time.
The main objective of this note is to report the presence and the possible shift of food source of the Geotrupinae dung beetle Ceratotrupes fronticornis in private gardens of Mexico City (Mexico).

Observations of dung beetles arriving to dog dung were made in two private gardens at peripheral colonies in Mexico City between 2010 and 2012. Both gardens are located on the slopes of Sierra de Las Cruces Mountains belonging to the Transverse Volcano Belt. Both gardens are partially covered with grass and sparse trees such as pines and oaks. In both properties, dogs were nourished with industrial dry dog food.

Garden A: Emilio Carranza 105. Magdalena Contreras colony (19॰18'9.7'N and 99 14'38'W). $2500 \mathrm{~m}$ asl.

Garden B: Bosque de la Reforma 1415. Bosque de Las Lomas colony. Cuajimalpa (19²4' $18^{\prime \prime} \mathrm{N}$ and $99^{\circ} 13^{\prime}$ 46 ”W). $2600 \mathrm{~m}$ asl.

Ceratotrupes fronticornis (Erichsson), a middle-sized Geotrupinae dung beetle species, endemic to Mexico was present in the gardens. It was remarkable the frequent appearance of several individuals of $C$. fronticornis that were feeding, and also burying dog-dung for nesting purposes. Additionally, individuals of this species were observed to be attracted to artificial lights. During the rainy seasons, the quantity of individuals observed increased.

Ceratotrupes fronticornis is a Mexican endemic species, characteristic of the highlands of the Mexican Traverse Volcanic Belt. Ceratotrupes fronticornis is usually is established in altitudes between 2200-2800 m asl, usually attracted to equine excrements (Halffter \& Martinez 1962). Our findings show that $C$. fronticornis is not restricted to mixed forest of Quercus and Pinus (Halffter \& Martinez 1962), this species is also present and abundant in certain urban areas of Mexico City. Moreover, C. fronticornis is using an alternative food source showing the ecological plasticity of this species in certain peripheral areas of Mexico City. Similar observations have been made for other dung beetles. Cave (2005) found 16 species feeding on dog-dung in Austin, Texas (USA). In addition, 
in a green urban area in Rome, Italy, the assemblage of dung beetles shifted from sheep to dog dung as the main source of food between 1986 and 1999 (Carpaneto et al. 2005).

As most urban areas hold an increasing quantity of dogs (Beck 1975) the daily production of dog excrement is high (Beaver 1975, Saitoh \& Itagaki 1990). Urban dung beetles fulfill an important role by eating and scavenging excrements in the cities (Cave 2005, Nichols et al. 2008, Nichols \& Gomez 2014). There are still many questions to answer about the presence and natural history of C. fronticornis in urban areas. Is dog dung its main food source? Where are the limits of the distribution of C. fronticornis in Mexico City? What are the special conditions that allow this species to live in urban areas? The number of individuals of $C$. fronticornis in Mexico City has augmented or decreased in the last decades? What is the main ecological function of this species in urban areas? And what other dung beetle species are living in Mexico City?

ACKNOWLEDGEMENTS. The authors are very grateful with Maria del Carmen Halffter† and to Regina Mijares de Halffter who were the first ones to collect the specimens from Garden A and Garden B respectively. We are also grateful to Carlos Andres Cultid Medina who made useful suggestions about the manuscript. L. R-R was supported with a Ph. D. scholarship from CONACYT (213179/244461 Convocatoria 290649), an Educational Condonable Credit by COLCIENCIAS (Convocatoria 568-2012), and by the Doctoral Program of the Instituto de Ecología, A.C. (INECOL).

\section{LITERATURE CITED}

Beaver, P. C. 1975. Biology of soil-transmitted helminths: the massive infection. Health Laboratory Science, 12: 116-125.

Beck, A. M. 1975. The public health implications of urban dogs. American Journal of Public Health, 65: 1315-1318.

Carpaneto, G. M., Mazziotta, A. \& Piattella, E. 2005. Changes in food resources and conservation of scarab beetles: from sheep to dog dung in a green urban area of Rome (Coleoptera, Scarabaeoidea). Biological Conservation, 123: 547-556.

Cave, R. D. 2005. Observations of Urban Dung Beetles Utilizing Dog Feces (Coleoptera: Scarabaeidae). The Coleopterists Bulletin, 59: 400-401.

Czech, B., Krausman, P. R. \& Devers, P. K. 2000. Economic associations among causes of species endangerment in the United States. Bioscience, 50: 593-601.

Davis, A. J., Holloway, J. D., Huijbregts, H., Krikken, J., Kirk-
Spriggs, A. H. \& Sutton, S. L. 2001. Dung beetles as indicators of change in the forests of northern Borneo. Journal of Applied Ecology, 38: 593-616.

Department of Economic and Social Affairs, Population Division, United Nations. World Urbanization Prospects: The 2014 Revision, Highlights (ST/ESA/SER.A/352); United Nations: New York, NY, USA, 2014.

Fattorini, S. 2011. Insect extinction by urbanization: a long term study in Rome. Biological Conservation, 144: 370-375.

Favila, M. E. \& Halffter, G. 1997. The use of indicator groups for measuring biodiversity as related to community structure and function. Acta Zoológica Mexicana (n. s.), 72: 1-25.

Halffter, G. \& Martínez, A. 1962. Monografía del género Ceratotrupes Jekel (Coleopt., Scarab., Geotrup.). Ciencia, Mex. 21: 145159.

Halffter, G. \& Arellano, L. 2002. Response of Dung Beetle Diversity to Human-induced Changes in a Tropical Landscape. Biotropica, 34: 144-154.

McIntyre, N. E. 2000. Ecology of urban arthropods: A review and a call to action. Annals of the Entomological Society of America, 93: 825-835.

McKinney, M. L. 2008. Effects of urbanization on species richness: A review of plants and animals. Urban Ecosystems, 11: 161-176.

Nichols, E. \& Gómez, A. 2014. Dung beetles and fecal helminth transmission: patterns, mechanisms and questions. Parasitology, 141: 614-623.

Nichols, E., Spector, S., Louzada, J., Larsen, T., Amezquita, S., Favila,M. E. \& Network, T. S. R. 2008. Ecological functions and ecosystem services provided by Scarabaeinae dung beetles. Biological Conservation, 141: 1461-1474.

Ramírez-Restrepo, L. \& Halffter, G. 2016. Copro-necrophagous beetles (Coleoptera: Scarabaeinae) in urban areas: A global review. Urban Ecosystems, pp. 1-17. Published online: 03 February 2016. DOI 10.1007/s11252-016-0536-2

Saitoh, Y. \& Itagaki, H. 1990. Dung beetles, Onthophagus spp., as potential transport hosts of feline coccidia. Nihon Juigaku Zasshi, 52: 293-297.

Spector, S. 2006. Scarabaeine dung beetles (Coleoptera: Scarabaeidae: Scarabaeinae): an invertebrate focal taxon for biodiversity research and conservation. The Coleopterists Bulletin, 60: 71-83.

UN (United Nations). 2014. World Urbanization Prospects: The 2014 Revision, Highlights.

Vitousek, P. M., Mooney, H. A., Lubchenco, J. \& Melillo, J. M. 1997. Human domination of Earth's ecosystems. Science, 277: 494-499.

\section{LORENA RAMÍREZ-RESTREPO \& GONZALO HALFFTER}

Red de Ecoetología, Instituto de Ecología, A.C. Carretera antigua a Coatepec 351, El Haya, Xalapa 91070, Veracruz, México. <bioramirez@gmail.com><gonzalo.halffter@inecol.mx> 